

\section{VOL. XX.-1905.}

THE

\section{JOURNAL OF LARYNGOLOGY}

\section{RHINOLOGY, AND OTOLOGY;}

AN ANALYTICAL RECORD OF CURRENT LITERATURE

RELATING TO

\section{THE THROAT, NOSE, AND EAR.}

PUBLISHED MONTHLY.

If $\mathfrak{x} \pi \mathfrak{d} \mathfrak{o} \pi t$

ADLARD AND SON, BARTHOLOMEW CLOSE. 


\section{THE JOURNAL OF LARYNGOLOGY, RHINOLOGY, AND OTOLOGY.}

Founded in 1887 by MORELL MACKENZIE and NORRIS WOLFENDEN.

\section{Editors :}

JOHN MACINTYRE, M.B., M.Ch., F.R.S.E. ARTHUR SANDFORD, M.D., M.Ch.R.U.I. DUNDAS GRANT, M.A., M.D., F.R.C.S.Eng. W. MILLIGAN, M.D., M.Ch.

Managing Sub-Editor:

W. JOBSON HORNE, M.A., M.D., B.C.Cantab., M.R.C.P.Lond.

WITH THE CO-OPERATION OF

Drs. Price-Brown (Toronto), Cartaz (Paris), Bryson Delavan (New York), Dodd (Chicago), Donelan (London), Clayton Fox (London), Gray (Glasgow), Grazzi (Florence), HicGuet (Brussels), Middlemass Hunt (Liverpool), Hutchison (Brighton), Joal (Paris), Kelly (Glasgow), Lacoarret (Toulouse), Lichtwitz (Bordeaux), Lieven (Aix-la-Chapelle), John N. Mackenzie (Baltimore), Prof. Massei (Naples), McCall (Bournemouth), Meyjes (Amsterdam), Mrles (New York), Holger Mygind (Copenhagen), Chichele Nourse (London), Porter (St. Louis), Sachs (Hamburg), Sajous (Philadelphia), Sendziak (Warsaw), Sota (Seville), StClair Thomson (London), Hunter Tod (London), Woods (Dublin), Macleod Yearslex (London), and Ziem (Dantzic). 


\section{LIST OF PLATES.}

Plates I-IV. To Illustrate Dr. Albert A. Gray's DemonstraTION OF SPECIMENS PREPARED BY THE AUTHOR's Method to show the Membranous Labyrinth in Man and Lower Animals.

Portrait of the late Professor A. A. G. Guye, M.D.

To Illustrate Dr. Wyatt Wingrave's Case of Fibroma of the Auricle . . . 263

Plates I, II. To Illustrate Sir Victor Horsley's Address on Vertigo .

- Plates I-IV. To Illustrate Mr. A. H. Young's and Dr. W. Milligan's Paper on the Continuity of the Several Cavities of the Middle Ear

$460,462,464,466$

Portrait of the late Dr. Farquhar Matheson 565 Portrait of the late Professor Philipp Schech $6: 1$

\section{IILUSTRATIONS IN TEST.}

To Illustrate Dr. Wyatt Wingrave's Syringe for Intra. LARYNGEAL INJECTIONS . . . . . . . 46

To Illustrate Dr. H. Macnaughton-Jones's Case of Traumatic Perforation of the Trmpanic Membrane . . . 158

Temperature Chart of Mr. William C. Bull's Case of Cerebellar abscess following Acute Disease of the Middle Ear 251

To Illustrate Dr. H. Macnaughton-Jones's Case of Atresia of the Meatus

To Illustrate the Victor Electrical Air Compressor . . 296

To Illustrate the de Vilbiss Nebuliser $\quad$ • • • . 996

Figs. 1-10.-Diagrams to Illustrate Dr. Albert A. Gray's Paper on the Theorjes of Hearing . . . . 303-313

Figs. 1, 2.-To Illustrate Mr. B. Seymour Jones's Paper on Local Anesthesia for Aural Operations . . $\quad 426,427$ 


\section{CONTENTS.}

Editorial-

Visit of British Physicians and Surgeons to Paris (Section of Laryn-

$\begin{array}{lllllll}\text { gology and Otology) } & \ldots & \ldots & \ldots & \ldots & \ldots & 353\end{array}$

Special Articles-

Collodion : its Use when the Membrana Tympani and Malleal Ligaments are Relaxed.--W. Sohier Bryant ... $\quad \ldots \quad$...

Papilloma of the Naso-Pharynx simulating Epithelioma.-Tном⿰s J. $\begin{array}{lllllll}\text { Harris } & \ldots & \ldots & \ldots & \ldots & \ldots & \ldots\end{array}$

Fibroma of the Larynx in a Child, aged three years, necessitating Tracheo. tomy and Subsequent Laryngo-fissure for its Removal, followed by

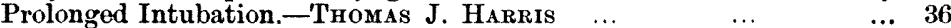

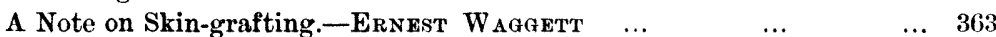

Societies' Proceedings-

Laryngological Society of London. Communications by Herbert Thluex, E. Wagante, Charters Symonds, J. Donelan, P. de Santi, Felix Shmon, Pinkus, Lambert Lack, Dundas Grant, H. J. Davis, Scanes Spicer, H. Barwel, G. C. Cathcart, W. H. Kelson, H. Smurthwaite, StChair Thomgon, Atwood Thorne, Charles Parker ...

Note-

British Medical Association Annual Meeting. Section of Laryngology,

Abstracts-

Fauces.-Foreign Bodies in the Throat

$\ldots$

Nose and Acckssory Sinuses.-Adenopathies in Affections of the Nasal Fossæ.-Empyema of Right Sphenoidal Cavity and Posterior Ethmoidal Cells, associated with Complete Occlusion of Right Posterior Naris.-Combined Empyema of the Left Frontal and Ethmoidal Cavities.-The Pathogenic Rôle of Alveolar Lesions in Prolonged Acute Maxillary Sinusitis

LARYNX. - A Case of Acute Syphilitic Laryngeal Stenosis ; Cure by Injection of Biniodide of Mercury.-Two Cases of Stenosis of Larynx, etc.-Eversion or Prolapse of the Ventricle of Morgagni ... $\quad \ldots \quad 396$

Trachra.-Obstruction of Left Bronchus by a Shoe-button ...

Therapeutics. - On the Treatment of Hay Fever.-The History of the Antitoxin Treatment of Diphtheria, with the Reasons for its Success

EAr.-A Case of Phlebitis of the Sinus with Pyæmia.-Mastoid Opera-

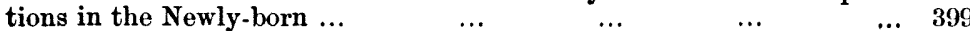

\section{Therapeutic Preparations-}

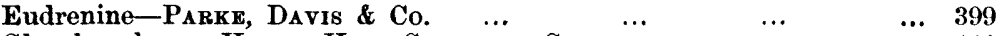

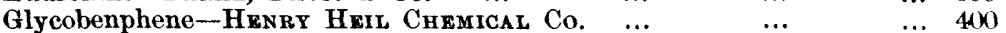

“'Tabloid" Quinine, Camphor and Aconite-Burrovahs Wellcome \& Co. 400

\section{Review -}

Adenoids.-Wrate Wingrave

\section{GUIDE TO ADVERTISEMENTS.}

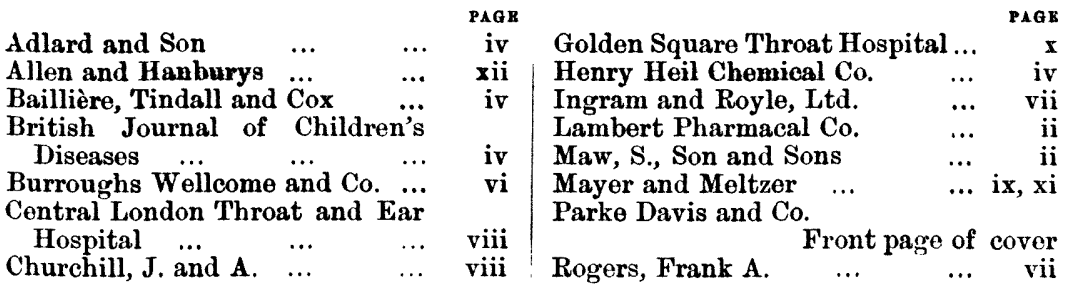




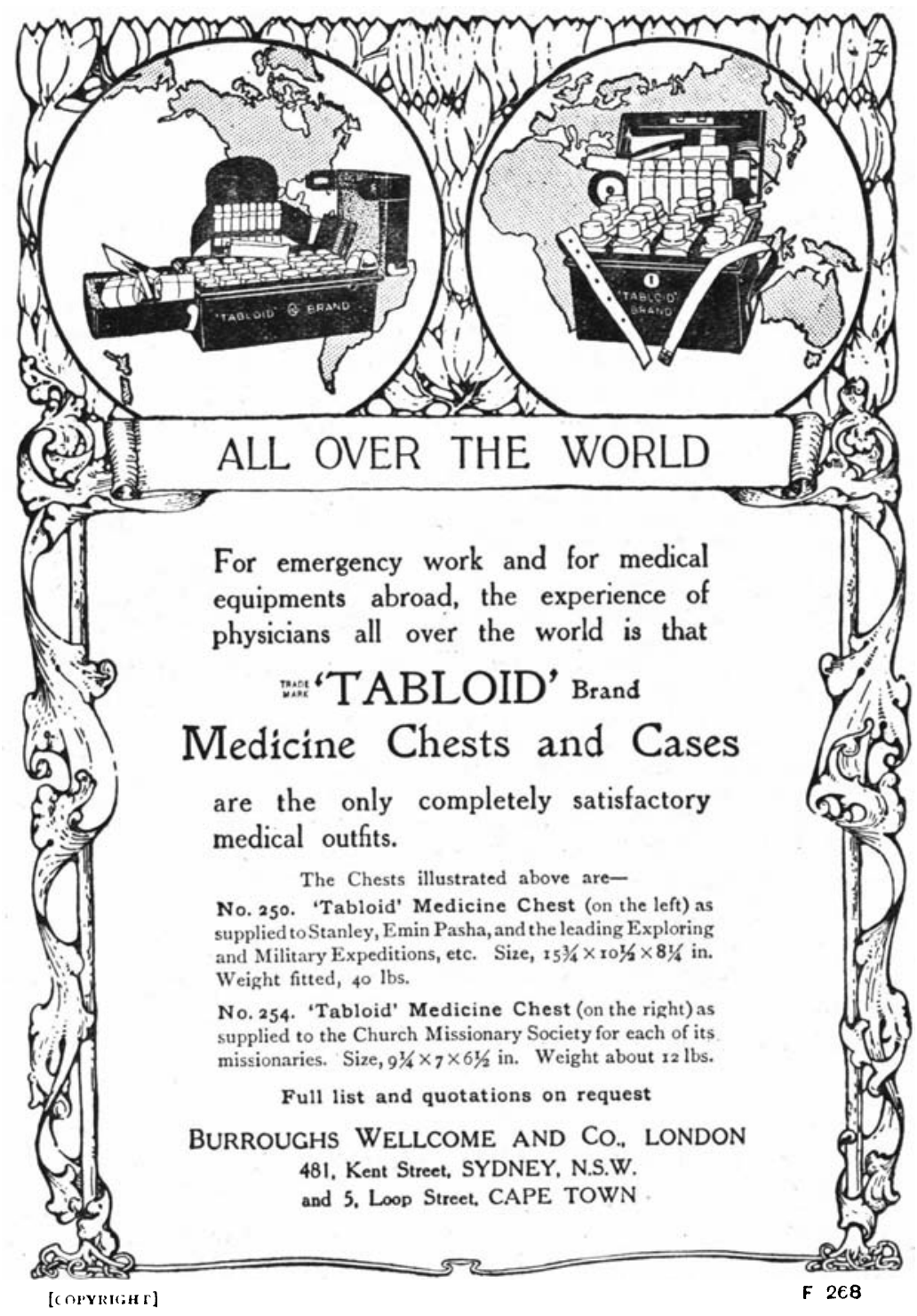

